\title{
Covid-19: schools set to close across UK except for children of health and social care workers
}

\author{
Elisabeth Mahase
}

The BMJ

Schools across the UK will close on Friday 20 March for the foreseeable future, but in England will still take the children of vital workers-such as NHS, social care, and delivery workers-and those who are vulnerable, the government has announced.

Speaking in parliament, education secretary for England Gavin Williamson said that "the spike of the virus is increasing at a faster pace than anticipated" and that the time had now come to act. He told early years providers, sixth forms, and colleges that they were also expected to follow the closure guidance.

"The public health benefits of schools remaining open as normal are shifting. It is also clear that schools are finding it more difficult to continue as normal, as illness and self-isolation impact on staffing levels and pupil attendance," he said. "After schools shut their gates on Friday afternoon they will remain closed until further notice."

Meanwhile, prime minister Boris Johnson announced that exams would be cancelled, but that students would still "get the qualifications they need and deserve for their future academic careers."

The announcement in England came hours after the Scottish and Welsh governments announced they were closing schools. Northern Ireland later followed suit, saying schools would be shut from Monday.

First minister of Scotland Nicola Sturgeon said, "People should not assume that schools will reopen after the Easter break. We will, of course, only keep them closed for as long as we absolutely must. But at this stage I cannot promise that they will reopen before the summer holidays."

As of 18 March, the UK had 2626 confirmed cases of covid-19—an increase of 676 compared with 17 March-and 104 deaths.

Williamson said that the scientific advice shows that having a small number of children (those of key workers and those who are vulnerable-meaning they have a social worker or health or education plans) at school would be safe. "Asking others to stay away will go towards helping us slow the spread of this virus," he said.

Speaking at the daily briefing, Johnson said, "By looking after the children of key workers, school staff will be a critical part of our fight against coronavirus."

The government also said it will give schools the flexibility to provide meals and vouchers to those children who are eligible for free school meals. The cost of these will be reimbursed and a national voucher scheme will soon be rolled out.

Speaking about the timing of this measure, chief scientific adviser Patrick Vallance said, "It's not because schools are dangerous places for children. They are the least at risk. The reason for this is the effect closing schools could have, to knock down transmission further and to protect those people that could end up in intensive care or on a ventilator."

Neil Ferguson-who carried out modelling at Imperial College London for the government's covid-19 response-previously warned that it would likely become "necessary quite quickly" to close schools, but that there were concerns over how this would impact healthcare capacity.

He said, "From memory, when we were in pandemic flu planning, we estimated that something like $25-35 \%$ of nurses have a child in school, perhaps higher.'

As well as closing schools, the UK government has implemented social distancing for everyone and 14 day whole household quarantining if anyone in the house has a covid-19 symptom. Those deemed high risk for severe disease-including pregnant women, people over 70, and those with certain health conditions-have been told to isolate themselves for 12 weeks, starting this weekend. ${ }^{1}$ In London, 40 underground stations have shut and bus services have been reduced.

Mahase E. Covid-19: UK starts social distancing after new model points to 260000 potential deaths. BMJ 2020;368:m1089. 10.1136/bmj.m1089 32184205

Published by the BMJ Publishing Group Limited. For permission to use (where not already granted under a licence) please go to http://group.bmj.com/group/rights-licensing/ permissions 